\title{
MANAJEMEN PENGETAHUAN PADA SEKTOR PUBLIK: SEBUAH TINJAUAN LITERATUR SISTEMATIS 2010-2021
}

\author{
Dwi Aryanti, Eko Prasojo \\ Ilmu Administrasi, Universitas Indonesia, Indonesia \\ dwi.aryanti@ui.ac.id
}

\begin{abstract}
Abstrak
Tulisan ini mengkaji fenomena manajemen pengetahuan pada organisasi sektor publik. Manajemen pengetahuan sektor publik merupakan area penelitian yang penting karena memiliki manfaat tidak hanya untuk organisasi itu sendiri namun juga kepentingan publik. Manajemen sektor publik di Indonesia merupakan bagian dari reformasi birokrasi sejak tahun 2010. Namun berdasarkan Knowledge Global Index, peringkat Indonesia masih berada dibawah rata-rata dunia. Kajian ini didasarkan pada tinjauan literatur sistematis dengan menggunakan database dari Scopus. Kumpulan dari 44 sumber jurnal dianalisis dengan menyajikan gambaran komprehensif manajemen pengetahuan sektor publik selama 10 tahun terakhir yakni dari tahun 2010 hingga Februari 2021. Makalah ini menjelaskan analisis deskriptif dan analisis konten. Pada analisis deskriptif digambarkan berupa lokasi, disiplin penelitian, metodologi, karakteristik, ukuran sampel dan tematik. Hasil analisis deksriptif penelitian menemukan bahwa terdapat tema dan area yang terlalu banyak dianalisis, sementara yang lain kurang diteliti. Selain itu, perlu melakukan pendekatan metodologis yang lebih dalam untuk memperkaya literatur. Pada analisis konten dijabarkan tentang urgensi manajemen pengetahuan pada sektor publik di Indonesia dan strategi yang diperlukan oleh pemerintah Indonesia dalam penerapannya.
\end{abstract}

Kata kunci: administrasi publik, manajemen pengetahuan, sektor publik, tinjauan literatur sistematis.

\begin{abstract}
This paper examines the phenomenon of knowledge management in public sector. Public sector knowledge management is an important area of research because it has benefits not only for the organization itself but also for the public interest. Public sector knowledge management in Indonesia is part of bureaucratic reform since 2010. However, based on the Knowledge Global Index, Indonesia's ranking is still below the world average. This review is based on a systematic literature review using the Scopus database. A collection of 44 journal sources is analyzed providing a comprehensive overview of public sector knowledge management over the past 10 years from 2010 to February 2021. This paper describes descriptive analysis and content analysis. Descriptive analysis is described in the form of location, research background, methodology, characteristics sample and research thematic. The results of the study found that there were themes and areas that were
\end{abstract}


over-analyzed, while others were under-investigated. In addition, future researchers should also take a deeper methodological approach to enrich the literature. The content analysis describes the urgency of knowledge management in the public sector in Indonesia and the strategies the Indonesian government needs in implementing public sector knowledge management.

Keywords: knowledge management, public administration, public sector, systematic review of the literature

\section{PENDAHULUAN}

Reformasi birokrasi yang diprakarsai dalam Peraturan Presiden Nomor 81 Tahun 2010 tentang Grand Design Reformasi Birokrasi, menjelaskan terdapat 8 (delapan) bidang yang saling terkait satu sama lain. Selanjutnya pada PermenpanRB Nomor 14 Tahun 2011, turut mendorong perlunya manajemen pengetahuan. Pada reformasi birokrasi, manajemen pengetahuan dapat menjadikan birokrasi mencapai kondisi yang diinginkan organisasi (Gambar 1). Menurut Prasojo (2020), knowledge-based bureaucracy sebagai agenda birokrasi pada reformasi yang mendasarkan pelaksanaan kerja berdasarkan pengetahuan, data, informasi dan bukti yang ada. Pemerintahan berbasis manajemen pengetahuan dari yang semula berdasarkan otoritas menjadi pembangunan berdasarkan pengetahuan sehingga dapat meningkatkan pelayanan publik.

Gambar 1. Kerangka Manajemen Pengetahuan dalam Reformasi Birokrasi

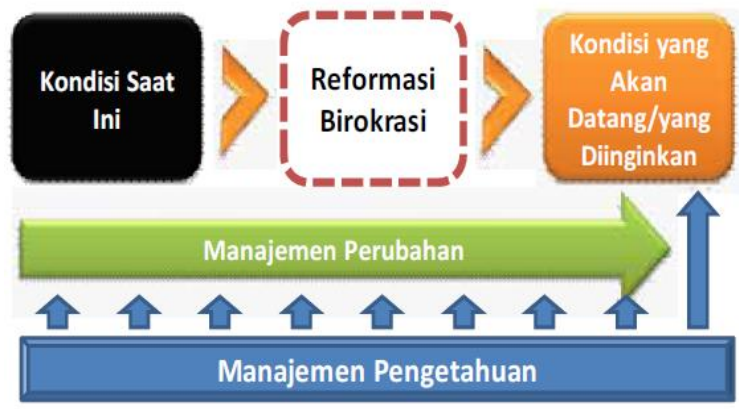

Sumber: KemenpanRB (2011)

Penerapan manajemen pengetahuan di Indonesia belum optimal. Pada laporan Bappenas (2016) dijelaskan bahwa penerapan di Indonesia belum masif karena masih difokuskan kepada Unit Pengelola Reformasi Birokrasi Nasional. Selain itu, United Nations Development Programme (UNDP) telah meneliti Global 
Knowledge Index yang dibuat untuk melihat kinerja pengetahuan suatu negara yang mencakup 7 (tujuh) bidang. Hasilnya pada tahun 2020, Indonesia menempati peringkat 81 dari 138 negara dengan skor indeks sebesar 43,3 sehingga masih dibawah rata-rata dunia dengan skor indeks 46,7. Pada wilayah ASEAN, Indonesia menempati urutan ke 7 (tujuh) sehingga berada dibawah 6 (enam) negara lainnya. Area perbaikan yang masih tertinggal terutama pada bidang penelitian, pengembangan dan inovasi dengan skor indeks sebesar 15,4 sehingga menduduki peringkat ke 102 dunia.

Tabel 1. Nilai GKI Negara ASEAN

\begin{tabular}{lcc}
\hline \multirow{2}{*}{ Negara } & Global Knowledge Index 2021 \\
\cline { 2 - 3 } Singapura & Peringkat & Nilai \\
Malaysia & 7 & 69,2 \\
Brunei & 33 & 55,6 \\
Thailand & 51 & 48,5 \\
Filipina & 53 & 48,3 \\
Vietnam & 60 & 46,4 \\
Indonesia & 66 & 46,6 \\
Kamboja & 81 & 43,3 \\
Laos & 90 & 41,7 \\
Myanmar & 105 & 37,4 \\
\hline Sumber: UNDP (2020) & 40,6 \\
\hline
\end{tabular}

Dana riset pengembangan ilmu pengetahuan di Indonesia memang telah mengalami kenaikan namun baru mencapai 0,25\% dari Produk Domestik Bruto (PDB) (Kemenkeu, 2019). Pada negara lain, tingkat ideal yakni sebesar 1\% dari PDB per tahun, di Filipina anggaran riset telah mencapai 0,82\%, di Jepang sebesar 1,3\% dan di Amerika Serikat telah mencapai 4\%. Selain kuantitas yang belum ideal, kualitas penelitian juga masih rendah. Hal ini diperkuat pada laporan dari Centre for Innovation Policy and Governance \& The Global Development Network yang menjelaskan rendahnya kualitas kinerja riset ilmu sosial di Indonesia (Rakhmani, Sakhiyya, Ramadhan, \& Agahari, 2020).

Hasil penelitian Mafabi, Munene, and Ntayi (2012) menemukan bahwa terdapat hubungan positif dan signifikan yang kuat antara manajemen pengetahuan dan inovasi organisasi. Ketika suatu organisasi meningkatkan pengetahuan yang dimilikinya, sehingga kemungkinan mengarah pada inovasi tertentu misalnya pembangunan infrastruktur, proses atau kompetensi. Manajemen pengetahuan juga 
berpotensi dalam mempengaruhi proses pembaruan sektor publik (Edge, 2005) dan bukan lagi hanya sebagai pilihan tetapi keharusan jika ekonomi ingin bertahan pada era liberalisasi dan globalisasi (De Angelis, 2013). Selain itu, manajemen pengetahuan sebagai fasilitator yang kuat untuk meningkatkan efisiensi pada pemerintah daerah (McAdam, Hazlett, \& Casey, 2005).

Meskipun telah terbukti memiliki banyak manfaat pada sektor publik, namun terdapat tantangan. Hal ini didukung oleh penelitian dari Titi Amayah (2013) yang menjelaskan bahwa tujuan organisasi sektor publik lebih sulit diukur dibandingkan sektor swasta dan dipengaruhi politik. Sulitnya penerapan manajemen pengetahuan juga dapat disebabkan karena organisasi publik umumnya bersifat birokrasi berlebihan, formalitas dan hirarki yang tradisional (Farazmand, 2017). Liebowitz (2003) menjelaskan bahwa karakteristik organisasi publik dapat membatasi pertukaran dan berbagi informasi dan pengetahuan. Berdasarkan uraian tersebut, kesulitan implementasi manajemen pengetahuan terjadi bukan hanya di Indonesia tetapi juga masalah dunia yang telah diteliti oleh banyak orang. Sehingga, makalah ini ditulis karena fenonema permasalahan manajemen pengetahuan sektor publik yang ada, baik yang terjadi di dunia maupun di Indonesia dengan melakukan tinjauan literatur sistematik di bidang ini. Makalah ini memiliki kebaruan dengan menggunakan metode tinjauan literatur sistematis pada riset 10 tahun terakhir (2010-2021). Oleh karena itu, penelitian ini berupaya menjawab pertanyaan penelitian: bagaimana analisis tinjauan literatur sistematis atas penelitian dan publikasi terhadap manajemen pengetahuan di Indonesia dilihat dari sisi deskriptif dan konten penelitian?

Penelitian ini menggunakan tinjauan literatur sistematis yang memungkinan peneliti untuk mengevaluasi literatur tertentu dan mengidentifikasi kontribusi untuk suatu bidang penelitian (Jesson, Matheson, \& Lacey, 2011). Penulis mengadopsi tinjauan literatur sistematis dari pendekatan Tranfield, Denyer, and Smart (2003) karena dapat direplikasi dan memberikan struktur yang jelas untuk proses seleksi literatur. Ruang lingkup tinjauan dibatasi untuk jurnal penelitian empiris manajemen pengetahuan pada sektor publik yang ditulis dalam bahasa Inggris pada tahun 2010 hingga Februari 2021. 
Proses pemilihan literatur melibatkan beberapa tahapan, seperti yang digambarkan pada Gambar 2. Setiap tahapan bertujuan untuk menambah atau mengurangi jumlah artikel yang relevan menurut kriteria yang telah ditentukan sebelumnya. Tahap pertama, pencarian terkomputerisasi yang dilakukan pada bulan Maret 2021. Database abstrak dan kutipan Scopus adalah alat pilihan untuk melakukan pencarian karena akurasi dan cakupan yang sangat baik dari literatur akademis (Falagas et al. 2008). Pada tahap selanjutnya, artikel diseleksi berdasarkan judul (tahap 2), abstrak (tahap 3) dan teks lengkap (tahap 4). Pada tahap kelima, dari daftar referensi artikel yang terseleksi ditemukan artikel lain yang tidak ditemukan selama tahap awal dalam proses pemilihan literatur.

Gambar 2. Proses Seleksi Literatur

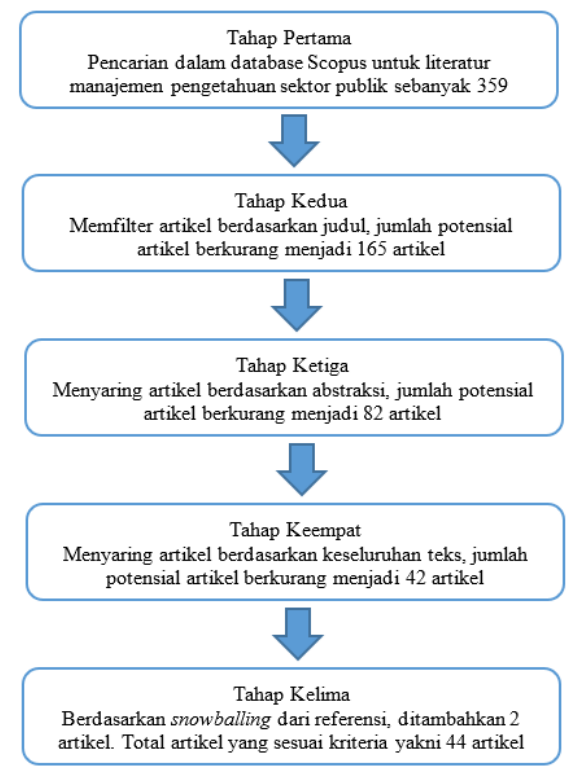

Sumber: Hasil olahan data penelitian, 2021

Tahap terakhir dalam tinjauan literatur sistematis dengan menambahkan tingkat ketelitian pada proses metodologis. Pilihan akhir dari 44 artikel dibaca dengan cermat untuk melihat apakah cocok dengan pertanyaan penelitian. Langkah ini disebutkan oleh Tranfield et al. (2003) untuk membantu dalam mengurangi bias. Mengingat jumlah jurnal yang terbatas, tidak diperlukan software khusus untuk mendukung penandaan dan pelabelan jurnal. 


\section{PEMBAHASAN}

Pada pembahasan, penulis akan membahas analisis deskriptif dan analisis konten. Penulis menyajikan beberapa statistik deskriptif tentang perkembangan publikasi berupa jumlah publikasi, negara tempat penelitian dilakukan, latar belakang disiplin ilmu, jenis penelitian, metodologi yang diterapkan, sampel dan tematik. Selanjutnya yakni pembahasan pada analisis konten. Pada dasarnya tinjauan literatur sistematis adalah suatu bentuk analisis konten dimana unit analisis adalah artikel (Krippendorff, 2013). Untuk analisis konten, penulis mensintesis isi dari jurnal terpilih yang selanjutnya akan dikaitkan dengan kondisi manajemen pengetahuan sektor publik di Indonesia. Analisis konten dipilih karena dapat digunakan untuk menganalisis data kualitatif secara kuantitatif atau kualitatif dari data sekunder.

\section{A. Analisis Statistik Deskriptif}

\section{Publikasi Pertahun}

Jurnal yang diterbitkan pada tahun 2010 sebanyak 2 (dua) jurnal. Antara tahun 2011 dan 2015 terdapat 10 jurnal. Meningkatnya jumlah publikasi selama tahun 2016 hingga tahun 2019 menunjukkan bahwa telah menarik peneliti terhadap topik manajemen pengetahuan sektor publik (26 dari 44), dengan puncaknya pada tahun 2016 sebanyak 10 penelitian. Selanjutnya pada tahun 2020 hingga Februari 2021, jumlah jurnal yang diterbitkan sebanyak 6 (enam) jurnal.

Gambar 3. Jumlah publikasi pertahun $(n=44)$

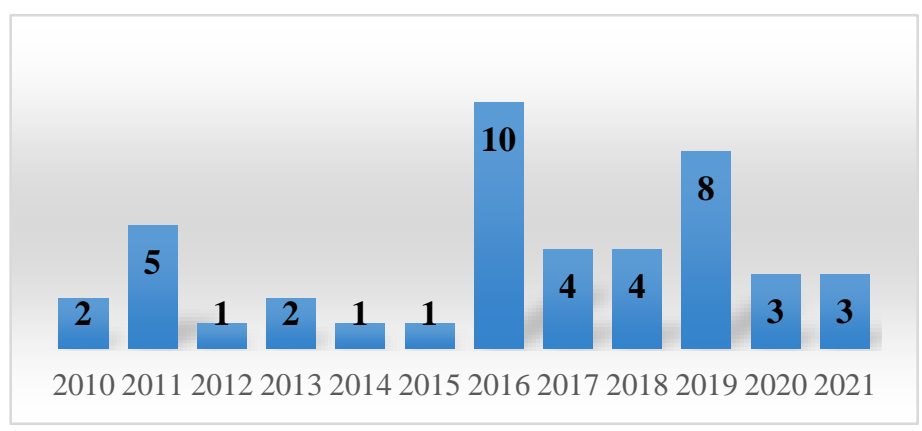

Sumber: Hasil olahan data penelitian, 2021 


\section{Latar Belakang Disiplin Penelitian}

Mayoritas makalah (15 dari 44) diterbitkan pada jurnal manajemen pengetahuan dan diikuti oleh 12 makalah dari disiplin manajemen dan ekonomi. Selanjutnya diikuti oleh jurnal sistem informasi dengan 6 (enam) makalah. Lima jurnal muncul pada jurnal pemerintah dan administrasi publik, 2 (dua) dari ilmu sosial dan lainnya berasal dari multidisiplin seperti perpustakaan, ekologi, governansi dan organisasi.

Gambar 4. Area subjek penelitian

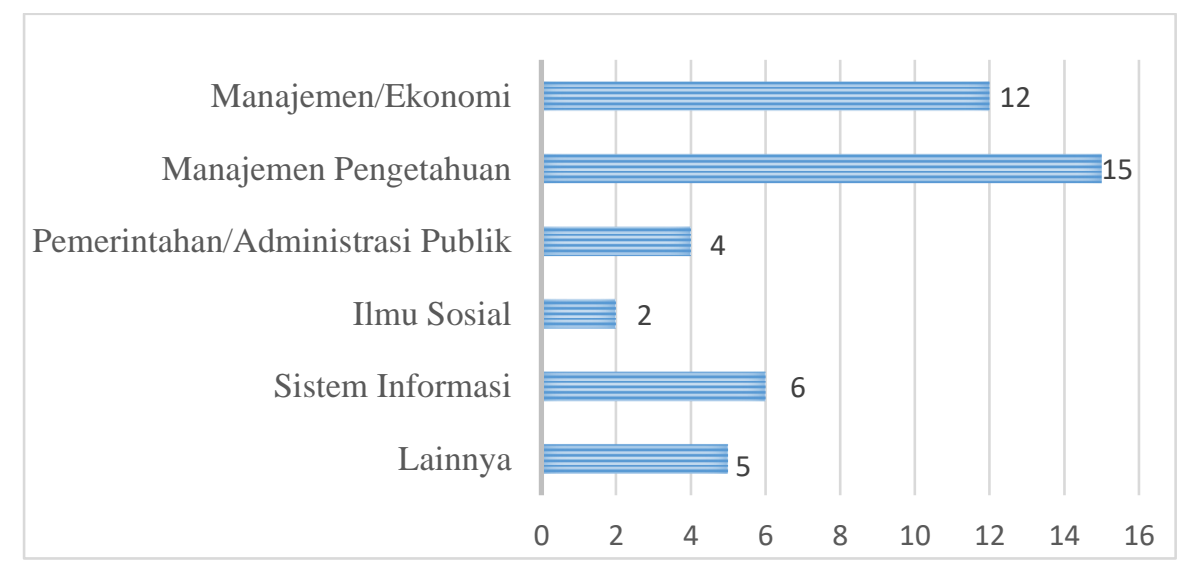

Sumber: Hasil olahan data penelitian, 2021

\section{Distribusi Regional}

Hasil lokasi penelitian menunjukkan bahwa Asia adalah wilayah yang paling banyak dipelajari (29 dari 44 penelitian) mewakili 66 persen. Hal ini bisa terjadi karena semakin penting Asia dalam hal ekonomi global. Uni Emirat Arab dan India merupakan negara yang mayoritas dianalisis dengan 5 (lima) jurnal. Malaysia sebagai negara ketiga yang paling banyak dianalisis dengan 4 (empat) jurnal. Wilayah Eropa dengan 6 (enam) jurnal, wilayah lain seperti Amerika dan Afrika sebanyak 4 (empat) jurnal dan wilayah Australia dengan 1 (satu) jurnal. 
Tabel 2. Distribusi regional penelitian

\begin{tabular}{|c|c|c|c|}
\hline \multirow{2}{*}{$\begin{array}{l}\text { Regional } \\
\text { Eropa }\end{array}$} & \multicolumn{3}{|c|}{ Negara } \\
\hline & 6 & Inggris & 1 \\
\hline & & Slovenia & 1 \\
\hline & & Serbia & 1 \\
\hline & & Finlandia & 2 \\
\hline & & Portugis & 1 \\
\hline Asia & 29 & Pakistan & 3 \\
\hline & & Malaysia & 4 \\
\hline & & Arab Saudi & 2 \\
\hline & & India & 5 \\
\hline & & Kuwait & 1 \\
\hline & & Palestina & 1 \\
\hline & & Singapura & 1 \\
\hline & & Iran & 2 \\
\hline & & Hongkong & 1 \\
\hline & & Dubai & 1 \\
\hline & & Uni Emirat Arab & 5 \\
\hline & & Indonesia & 1 \\
\hline & & Iraq & 1 \\
\hline & & Taiwan & 1 \\
\hline Amerika & 4 & Kanada & 1 \\
\hline & & Brasil & 2 \\
\hline & & New York & 1 \\
\hline Afrika & 4 & Afrika Selatan & 1 \\
\hline & & Uganda & 1 \\
\hline & & Mauritius & 1 \\
\hline & & Ghana & 1 \\
\hline Australia & 1 & & \\
\hline
\end{tabular}

Sumber: Hasil olahan data penelitian, 2021

\section{Metode Penelitian}

Berkenaan dengan metode penelitian yang digunakan, dapat dilihat dominasi yang jelas dari penelitian kuantitatif dengan menggunakan survei (28 dari 44 jurnal) sebanyak 64\%. Empat makalah menggabungkan setidaknya 2 (dua) metode seperti survei dan wawancara. Satu studi penelitian dengan gabungan diskusi grup dan wawancara, sementara studi lainnya menggunakan metode Delphi sebagai metode peramalan. Mafabi et al. (2012) mengadopsi desain cross-sectional untuk mengumpulkan data yang biasa digunakan untuk melakukan analisis mediasi. Enam penelitian menerapkan pendalaman studi kasus, misalnya Laihonen and Kokko (2020) mendasarkan analisa mendalam tentang proyek di Finlandia sehingga bisa mendapatkan detail informasi tentang kondisi, peristiwa dan proses terkait kejadian. 
Gambar 5. Metode Penelitian

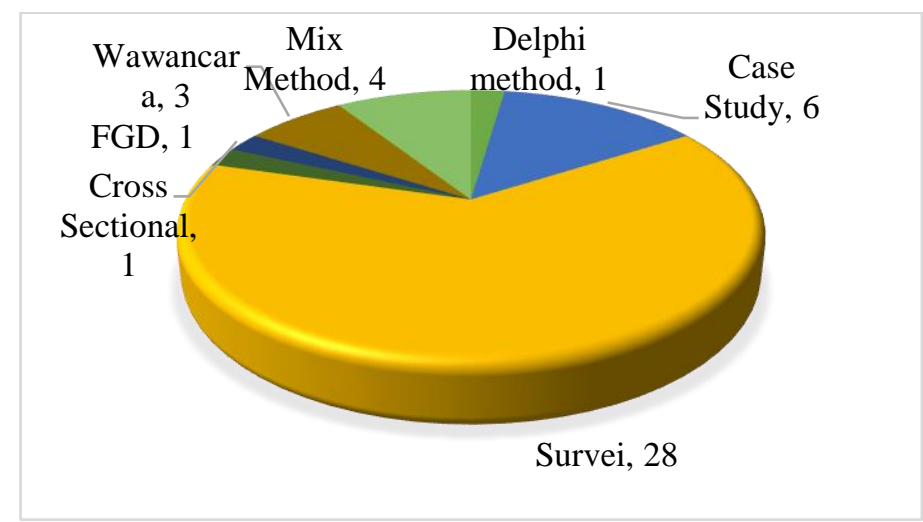

Sumber: Hasil olahan data penelitian, 2021

\section{Karakteristik Sampel dan Ukuran Sampel}

Studi dalam sampel penelitian ini terutama melibatkan karyawan yakni 20 penelitian. Selanjutnya penelitian yang melibatkan sampel manajer dan pimpinan sebanyak 12 penelitian, diikuti oleh sampel akademisi sebanyak 5 (lima) penelitian dan 1 (satu) jurnal memiliki sampel pelajar, sedangkan 6 (enam) lainnya tidak disebutkan secara detail. Untuk ukuran sampel penelitian, mayoritas dengan data kurang dari 100 sampel sebanyak 18 studi atau 40,9\%. Hanya 1 (satu) penelitian melibatkan populasi lebih dari 500 peserta. Ukuran rata-rata sampel dari 44 studi (diluar dari 6 studi yang tidak menyebutkan secara spesifik) adalah 166 sampel.

Tabel 3. Ukuran Sampel Penelitian

\begin{tabular}{|l|c|c|c|}
\hline Ukuran Sampel & $\begin{array}{c}\text { Jumlah } \\
\text { Penelitian }\end{array}$ & $(\%)$ & $\begin{array}{c}\text { Akumulasi } \\
(\%)\end{array}$ \\
\hline$<\mathbf{1 0 0}$ & 18 & 40,9 & 40,9 \\
\hline $\mathbf{1 0 0}-\mathbf{1 9 9}$ & 3 & 6,8 & 47,7 \\
\hline $\mathbf{2 0 0}-\mathbf{2 9 9}$ & 8 & 18,2 & 65,9 \\
\hline $\mathbf{3 0 0}<\mathbf{4 0 0}$ & 7 & 15,9 & 81,8 \\
\hline $\mathbf{4 0 0} \mathbf{5 0 0}$ & 1 & 2,3 & 84,1 \\
\hline $\mathbf{5 0 0}$ & 1 & 2,3 & 86,4 \\
\hline Tidak disebutkan & 6 & 13,6 & 100 \\
\hline & 44 & & \\
\hline
\end{tabular}

Sumber: Hasil olahan data penelitian, 2021

\section{Tematik}

Analisis tematik diakui sebagai metode untuk mengidentifikasi tema dan pola dalam data penelitian tertentu (Ward, House, \& Hamer, 2009). Peneliti mengelompokkan 44 jurnal terpilih menjadi 7 (tujuh) kategori tematik. Kapabilitas manajemen pengetahuan menjadi kategori terbesar yakni 14 jurnal (31,8\% dari 
sampel). Tema kedua yang paling banyak dianalisis yakni praktik manajemen pengetahuan dengan 9 (sembilan) artikel yang mewakili 20,5\% dari sampel. Selanjutnya 6 (enam) artikel terkait analisis faktor pendukung dan hambatan manajemen pengetahuan. Kategori selanjutnya yakni strategi manajemen pengetahuan dan kepemimpinan dengan 3 (tiga) artikel masing-masing, berbagi pengetahuan sebanyak 2 (dua) artikel dan lainnya yakni terkait inovasi, digitalisasi pemerintah dan keberlanjutan dengan 7 (tujuh) artikel.

Gambar 6. Kategorisasi Jurnal Terpilih

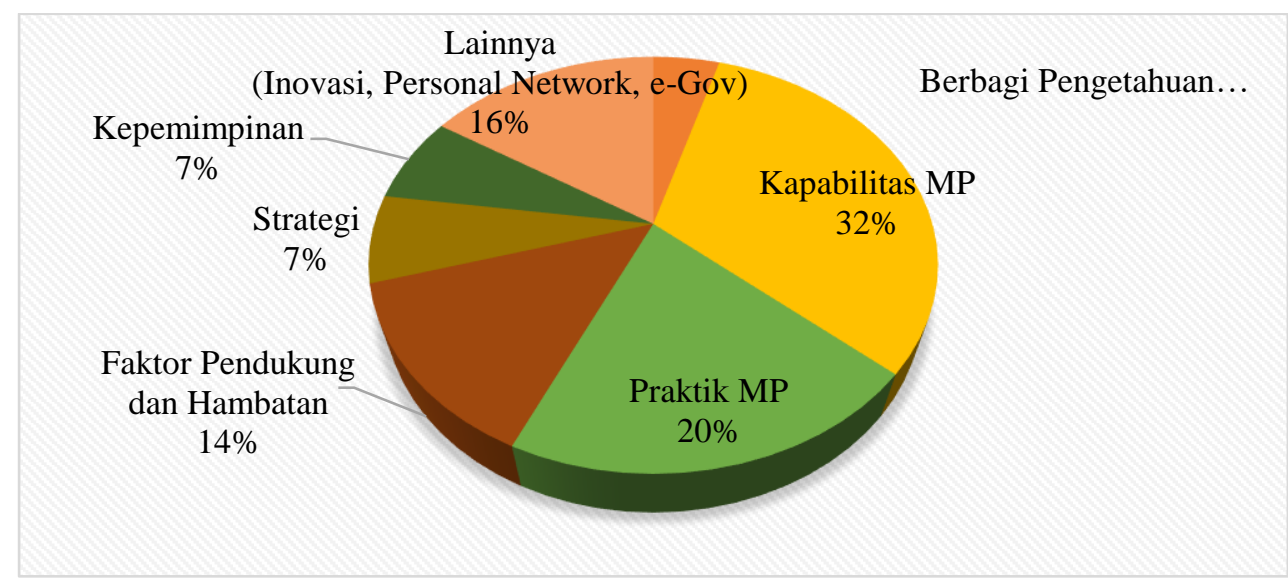

Sumber: Hasil olahan data penelitian, 2021

\section{B. Analisis Konten}

Dalam artikel terpilih, ditemukan bahwa 3 (tiga) negara yakni Uni Emirat Arab, India dan Malaysia adalah negara yang mayoritas dipelajari pada manajemen sektor publik. Hal ini mungkin sebagai hasil kebijakan pada negara-negara tersebut untuk mempromosikan manajemen pengetahuan. Pada Uni Emirat Arab, perhatian yang tumbuh dari pemerintah yang mendukung manajemen pengetahuan sebagai bagian dari visi 2021 menuju transisi ekonomi berbasis minyak menjadi ekonomi berbasis pengetahuan setelah terjadi penurunan harga minyak (Al Yami, Ajmal, Balasubramanian, \& Systems, 2021). Pada India, bahwa laju pertumbuhan ekonomi dan industrialisasi yang cepat, sehingga sektor publik perlu berpartisipasi sehingga dapat terus kompetitif (Pandey \& Dutta, 2015). Manajemen pengetahuan juga dianggap penting bagi Pemerintah Malaysia karena pemerintah berpendapat bahwa penerapan manajemen pengetahuan pada sektor publik dapat membawa dampak yang lebih besar pada warganya dibandingkan dengan perusahaan swasta (Choy 
Chong, Salleh, Noh Syed Ahmad, \& Syed Omar Sharifuddin, 2011). Besarnya perhatian yang tumbuh dari pemerintah memicu perkembangan studi yang difokuskan pada negara-negara ini. Efek sampingnya yakni makin banyaknya studi yang berfokus pada area yang sama, sementara area lain yang hampir diabaikan, misalnya hanya terdapat 1 (satu) sampel penelitian di Indonesia.

Penemuan tinjauan literatur juga menunjukkan konsentrasi studi yang tinggi pada satu kelompok topik yakni terkait kapabilitas manajemen pengetahuan yang dapat mencakup faktor-faktor pendukung serta prosesnya. Pada saat yang sama, penelitian sebaiknya juga meneliti pada tema-tema yang belum diteliti. Selain itu, peneliti manajemen pengetahuan harus berpikir ulang dalam melakukan pendekatan metodologis karena hampir sebagian besar penelitian melakukan teknik survei melalui kuesioner untuk mendapatkan data, sehingga perlu ada pendekatan lain yang dikembangkan secara kritis sehingga dapat memberikan kontribusi yang berarti pada literatur untuk lebih mengembangkan pendekatan kritis.

Urgensi Manajemen Pengetahuan Sektor Publik Sehingga Perlu diterapkan di Indonesia

Banyak literatur yang menjelaskan manfaat manajemen pengetahuan pada sektor publik. Pada sampel penelitian, beberapa studi menemukan korelasi positif dan signifikan dari manajemen pengetahuan sektor publik terhadap kinerja organisasi (Al Ahbabi, Singh, Balasubramanian, \& Gaur, 2019; Siddiqui, Rasheed, Nawaz, \& Abbas, 2019). Manajemen pengetahuan juga sebagai prediktor yang kuat, positif dan signifikan untuk terbentuknya smart government (Albreiki \& Bhaumik, 2019). Pada smart government, manajemen pengetahuan menyediakan strategi keseluruhan untuk mengelola konten pemerintahan elektronik dengan menyediakan alat dan teknik organisasi pengetahuan, memantau kemutakhiran konten pengetahuan dan menyediakan semua informasi yang diperlukan untuk warga negara sehingga pengetahuan lebih dapat digunakan, diakses serta disimpan. Menurut hasil penelitian Alvarenga, Matos, Godina, and C. O. Matias (2020) bahwa keberhasilan pemerintahan digital terkait dengan kualitas manajemen pengetahuan.

Pada Table 4 berisikan nilai E-Government Development Index (EDGI) pada negara ASEAN selama 10 tahun terakhir. Pada tahun 2020, Indonesia 
mendapatkan peringkat ke 86, naik 19 peringkat dari tahun 2018. Indonesia menempati peringkat ke 7 (tujuh) di ASEAN setelah Vietnam, peringkat ini masih jauh dibawah negara ASEAN lainnya seperti Singapura (peringkat ke 11) dan Malaysia (peringkat ke 47). Nilai rata-rata EDGI Indonesia yakni 0,6612 berada sedikit diatas rata-rata Asia Tenggara dengan nilai 0,6321.

Tabel 4. Nilai EGDI Negara ASEAN

\begin{tabular}{lcccccc}
\hline \multirow{2}{*}{$\begin{array}{c}\text { Peringkat } \\
\text { Negara di ASEAN }\end{array}$} & $\mathbf{6 0 2 0}$ & $\mathbf{2 0 1 8}$ & $\mathbf{2 0 1 6}$ & $\mathbf{2 0 1 4}$ & $\mathbf{2 0 1 2}$ & $\mathbf{2 0 1 0}$ \\
\cline { 2 - 6 } Indonesia & 88 & 107 & 116 & 106 & 97 & 10 \\
Malaysia & 47 & 48 & 60 & 52 & 40 & 32 \\
Singapura & 11 & 7 & 4 & 3 & 10 & 11 \\
Viet Nam & 86 & 88 & 89 & 99 & 83 & 90 \\
Thailand & 57 & 73 & 77 & 102 & 92 & 76 \\
Filipina & 77 & 75 & 71 & 95 & 88 & 78 \\
Laos & 167 & 162 & 148 & 152 & 153 & 156 \\
Myanmar & 146 & 157 & 169 & 175 & 160 & 141 \\
Brunei Darussalam & 60 & 59 & 83 & 86 & 54 & 87 \\
Kamboja & 124 & 145 & 158 & 139 & 155 & 140 \\
\hline
\end{tabular}

Sumber:(United Nations 2021), diakses pada 1 Maret 2021

Nilai EDGI yang rendah, salah satunya dapat disebabkan karena belum optimalnya manajemen pengetahuan di Indonesia. Hal ini dikuatkan dengan penelitian Rachmawati and Sensuse (2010), dimana Indonesia belum menerapkan kerangka manajemen pengetahuan dalam e-government karena saat ini $e$ government di Indonesia baru bersifat situs layanan saja.

Sejumlah organisasi publik telah menerapkan praktik manajemen pengetahuan dengan upaya untuk menciptakan sistem yang lebih inovatif untuk menghubungan orang dengan informasi dan pengetahuan. Ada berbagai contoh dalam literatur yang menyoroti keberhasilan penggunaan kebijakan dan solusi manajemen pengetahuan di berbagai tingkat pemerintah. Penelitian dari MagnierWatanabe, Benton, Senoo, and practice (2011) menjelaskan tentang penerapans manajemen pengetahuan yang kuat dari Korea Selatan. Pemerintah Korea Selatan mulai menerapkan manajemen pengetahuan secara sistematis pada tahun 1998 dan mengembangkan standar sistem manajemen pengetahuan dari berbagai instansi melalui Government Knowledge Management Center (GKMC). Pembentukan GKMC diharapkan dapat menjadi sarana pertukaran pengetahuan dalam organisasi pemerintah. Korea Selatan menjadikan inovasi pemerintah sebagai agenda prioritas 
untuk mengubah pemerintah dengan cara yang adaptif dengan masyarakat berbasis pengetahuan sehingga terbentuk pilar efisiensi dan transparansi.

Manajemen pengetahuan sektor publik pada negara berkembang masih perlu ditingkatkan. Hasil penelitian menunjukkan bahwa negara-negara Arab tertinggal jauh dibandingkan dengan negara maju dan perlu belajar banyak dari keberhasilan manajemen pengetahuan sektor publik di negara maju (Alatawi, Dwivedi, Williams, \& Rana, 2012). Penelitian dari Joshi, Farooquie, and Chawla (2016) menemukan bahwa manajemen pengetahuan sektor publik di India masih dalam tahap awal dan perlu perjalanan panjang untuk mengimbangi sektor swasta. Hal ini disebabkan karena sektor swasta telah mengembangkan pendekatan tersruktur untuk membangun manajemen pengetahuan secara sosial (diskusi) dan infrastruktur teknis (teknologi) serta telah menyelaraskan manajemen pengetahuan dengan tujuan dan sasaran organisasi.

Inisiatif manajemen pengetahuan yang berhasil dari negara maju telah berhasil mendapatkan keunggulan kompetitif. Pada Indeks Pengetahuan Global tahun 2020, peringkat pertama yakni negara Switzerland dengan kekuatannya berupa efektivitas pemerintah, ketersediaan layanan penelitian dan pelatihan, kualitas lembaga penelitian serta pelatihan staf. Pada wilayah ASEAN, Singapura sebagai peringkat ke 7 (tujuh) memiliki kekuatan pada keberhasilan dalam mempromosikan informasi teknologi.

Manajemen pengetahuan memanfaatkan pengetahuan yang tertanam pada orang-orang pada organisasi yang tertanam dalam pengalaman, keterampilan dan kebijaksanaan. Penerapan manajemen pengetahuan membantu aliran informasi dalam organisasi sehingga meningkatkan pengetahuan penggunaan organisasi melalui pembelajaran organisasi dengan tujuan memberikan nilai kepada organisasi. Perlunya keseriusan dari pemerintah Indonesia dalam menggarap manajemen pengetahuan pada sektor publik. Seperti yang dikemukakan oleh Wiig (2002) bahwa manajemen pengetahuan dapat membangun modal intelektual suatu bangsa dan meningkatkan efektivitas pengambilan keputusan publik. Zhou, Gao, and Security (2007) mengemukakan bahwa manajemen pengetahuan sektor publik dapat meningkatkan kompetensi pemerintah dan meningkatkan kualitas layanan. 


\section{Strategi untuk Meningkatkan Manajemen Pengetahuan di Indonesia}

Dalam mengelola pengetahuan organisasi, sangat penting untuk memiliki strategi manajemen pengetahuan yang dipahami karyawan. Memiliki strategi manajemen pengetahuan yang terencana dengan baik juga akan bermanfaat bagi organisasi, karena memungkinkan organisasi untuk mengakses dan menyimpan file informasi dan pengetahuan. Namun, menurut temuan dari Rowley and Seba (2010) bahwa pada badan polisi di Inggris tidak ada organisasi yang memiliki strategi atau kebijakan manajemen pengetahuan. Temuan ini konsisten dengan temuan Cong, Li-Hua, and Stonehouse (2007) bahwa terdapat kekurangan strategi yang jelas untuk mengimplementasikan manajemen pengetahuan.

Tanpa strategi yang jelas dan jelas tujuannya, kegiatan manajemen pengetahuan cenderung lebih sulit dalam organisasi publik. Sebagian besar karyawan di sektor publik melihat pengetahuan mereka sebagai kekuatan dan menjaga pengetahuan mereka untuk melindungi posisi (Al-Athari \& Zairi, 2001). Salleh, Ahmad, Ikhsan, and Chong (2011) menemukan bahwa kesulitan dalam mengubah perilaku dan sikap karyawan sebagai kendala terbesar, hambatan lainnya termasuk kurangnya kepercayaan.

Kurangnya kesadaran dan kurangnya strategi yang jelas, bersama dengan hambatan yang ada dalam organisasi publik ditemukan menghambat efektifitas manajemen pengetahuan (Cong et al., 2007). Sebagai langkah awal, mengembangkan strategi manajemen pengetahuan memerlukan analisis yang cermat terhadap visi, misi dan tujuan organisasi. Penelitian Al Yami and Ajmal (2019) menjelaskan bahwa Uni Emirat Arab telah menduduki peringkat pertama di dunia Arab dan peringkat ke-42 dunia karena sebagai salah satu negara yang telah mendukung program manajemen pengetahuan nasional sebagai bagian dari visi 2021 yakni menuju ekonomi berbasis pengetahuan. Salah satu strateginya dengan mendirikan Mohammed Bin Rashid Al Maktoum Foundation dengan dana sebesar \$10 miliar. Penelitian dari Abass, Hayat, Shahzad, and Riaz (2011) pada pemerintah Pakistan menemukan implikasi bahwa organisasi harus secara eksplisit mengakui 
pengetahuan sebagai elemen kunci dalam perencanaan strategis dan harus memiliki prosedur internal yang efektif untuk mentransfer seluruh praktik terbaik organisasi.

Pada Indonesia, manajemen pengetahuan sektor publik masuk kedalam program reformasi birokrasi pada tingkat meso yakni menjalankan fungsi manajerial yang dijalankan oleh unit khusus. Hasil penelitian Mitrović, Obradović, and Suknović (2018) menunjukkan meskipun manajemen pengetahuan dianggap penting dan prioritas namun tanpa adanya kebijakan formal dan tanggung jawab sehingga karyawan belum siap untuk melaksanakan secara informal. Sehingga pemerintah Indonesia perlu membuat kebijakan pemerintah yang dapat dimulai dengan membuat penilaian tentang tahap pengembangan maturitas manajemen pengetahuan sektor publik di Indonesia yang dimulai dengan pembentukan knowledge management system sehingga terdapat standarisasi mutu.

Mengingat urgensi manajemen pengetahuan sektor publik, maka perlunya peningkatan ke dalam tingkat pelaksana makro sehingga sebagai regulasi nasional yang selanjutnya dapat disesuaikan dengan karakteristik organisasi. Karena setiap organisasi memiliki memiliki perbedaan dalam sumber daya manusia, proses dan fungsi maka strategi manajemen pengetahuan bersifat unik. Implementasi strategi manajemen pengetahuan dapat dicapai melalui langkah-langkah berikut:

\section{Menganalisis Infrastruktur Pengetahuan}

Dengan mengidentifikasi infrastruktur, sehingga dapat melihat komponen yang dapat membantu dalam membangun strategi manajemen pengetahuan dan memanfaatkan apa yang telah ada. Selain itu, penting bagi organisasi sektor publik untuk menganalis kebijakan yang ada karena implementasi manajemen pengetahuan bergantung pada intervensi kebijakan dan infrastruktur. Banyak penelitian yang menanganalisis infrastruktur yang harus ada dalam mendukung manajemen pengetahuan. Penelitan Mitrović et al. (2018) pada pemerintah lokal Serbia menyebutkan infrastruktur berupa teknologi, budaya dan sumber daya manusia sebagai pendukung manajemen pengetahuan. Penelitian Salleh (2013) pada salah satu departemen Pemerintah Federal di Malaysia menjelaskan bahwa evaluasi kinerja dan insentif memiliki dampak yang tinggi pada kinerja berbagi pengetahuan. 
Pada salah satu infrastruktur yakni budaya organisasi, penelitian Sensuse, Cahyaningsih, and Wibowo (2015) menjelaskan budaya Pemerintah Indonesia lebih mirip sebagai budaya hierarki dan budaya marga dibandingkan budaya pasar, sehingga perlu adanya adaptasi organisasi baru sehingga tujuan budaya untuk mendefinisikan pengetahuan dapat relevan.

\section{Dukungan Pemimpin}

Kepemimpinan diakui sebagai faktor penting dalam keberhasilan manajemen pengetahuan. Penelitian Chu (2016) ditemukan bahwa manajemen pengetahuan tidak dapat dilaksanakan tanpa kepemimpinan yang efektif, khususnya dari awal proses manajemen pengetahuan karena perannya sebagai pemimpin visi, panutan, fasilitator dan memelihara budaya berbagi. Namun peran pemimpin yang bersifat eksploitatif memiliki dampak negatif terhadap manajemen pengetahuan (Abdulmuhsin, Zaker, \& Asad, 2021). Penelitian Karim and Valaei (2020) menjelaskan bahwa kepemimpinan transformatif secara positif dapat mempengaruhi proses manajemen pengetahuan.

Menurut penelitian Irawanto (2009) bahwa memimpin karyawan di Indonesia tidak sama dengan memimpin pada dunia barat atau Asia lainnya karena orang Indonesia menekankan kesejahteraan kolektif dan orientasi kemanusiaan yang kuat dalam masyarakat sehngga pemimpin yang efektif adalah yang menunjukkan rasa belas kasih yangtidak hanya menjadi manajer, tetapi juga menjadi pelindung dan mentor. Pentingnya dukungan pemimpin karena menurut Prasojo (2020), dari kasus yang terjadi di Indonesia, berbagai agenda reformasi birokrasi dapat berjalan karena kuatnya komitmen pemimpin instansi pemerintah.

\section{Merancang Tim Manajemen Pengetahuan.}

Pada persiapan manajemen pengetahuan perlu ada pembentukan tim manajemen pengetahuan yang akan merancang, membangun, mengimplementasikan dan menyebarkan sistem manajemen pengetahuan. Chiu and Chen (2016) melakukan penelitan pada organisasi publik di Taiwan dan menemukan jika pemerintah ingin menerapkan strategi manajemen pengetahuan maka membutuhkan kelompok atau individu yang berbagi pengetahuan untuk kepentingan bersama. Tim manajemen yang efektif adalah campuran dari 
pemangku kepentingan utama dan perlunya identifikasi sumber keahlian yang mampu menjaga keseimbangan persyaratan teknis dan manajerial sehingga membangun tim yang tepat.

\section{Mengembangkan Sistem Manajemen Pengetahuan}

Penelitian Colnar and Dimovski (2017) menjelaskan bahwa pada beberapa badan sektor publik di Slovania dan kasus negara lain seperti Singapura bahwa kesemuanya memiliki kesamaan yakni supaya berhasil dalam inisiatif manajemen pengetahuan maka perlu adanya teknologi yang bisa menjadi alat untuk berbagi pengetahuan seperti portal internet yang terseda untuk semua orang di organisasi. Selain itu, penelitian Alvarenga et al. (2020) menemukan pada Kementerian Lingkungan Portugis bahwa penggunaan teknologi dikombinasikan dengan penggunaan pengetahuan secara sistematis akan meningkatkan efisensi dan inovasi dalam organisasi publik serta memanfaatkan keterampilan dan pengetahuan karyawan dalam dukungan teknologi.

Penelitian di Indonesia yang dilakukan oleh Cahyaningsih, Sensuse, Wibowo, Latifah, and Sari (2016) meneliti pelaksanaan sistem manajemen pengetahuan pada tiga instansi pemerintah yang mengurus Aparatur Sipil Negara yakni Lembaga Administrasi Negara, Badan Kepegawaian Negara dan Kemenpan \& RB melalui platform Nusantara. Namun belum ditemukan objek penelitian yang lebih besar pada objek lainnya di pemerintahan terkait aplikasi yang mendukung proses manajemen pengetahuan secara nasional, karena setiap organisasi di pemerintah membangun sistem manajemen pengetahuan secara mandiri. Selain itu, tantangan pada pemerintah Indonesia yang memiliki kemampuan teknologi yang berbeda-beda pada masing-masing instansi, seperti penelitian Praditya (2012) yang membandingkan kesiapan teknologi manajemen pengetahuan pada pemerintah daerah Tangerang dan Palembang yang memiliki perbedaan hasil bahwa pemerintah daerah Tangerang telah memiliki infrastruktur teknologi yang cukup namun pemerintah daerah Palembang belum didukung sistem manajemen pengetahuan yang optimal. 


\section{Membuat Struktur Penghargaan}

Kegagalan proyek seperti implementasi manajemen pengetahuan dapat terjadi karena kurangnya dukungan karyawan. Mendorong karyawan untuk berbagi pengetahuan umumnya menjadi upaya sukarela sehingga diperlukan struktur penghargaan yang memotivasi karyawan untuk menggunakan sistem. Menurut Liebowitz (2003), terdapat budaya penimbunan pengetahuan pada pemerintahan karena karyawan enggan berbagi pengetahuan karena sebagai kekuatan karyawan itu sendiri dalam hal peningkatan pangkat. Hal ini dapat diatasi dengan memberi karyawan penghargaan bagi karyawan yang berbagi pengetahuan. Penelitan Salleh et al. (2011) pada pemerintah Malaysia menyebutkan bahwa organisasi sektor publik memiliki sumber daya yang terbatas sehingga jika tidak dapat memberikan insentif keuangan namun organisasi dapat mempertimbangkan jenis insentif lain seperti promosi dan peluang pengembangan karir, peluang pelatihan, penghargaan staf atau tim terbaik dan lainnya.

Penelitian yang dilakukan oleh Susanty, Yuningsih, and Anggadwita (2019) menemukan hasil yang menarik yang berbeda dengan penelitian pada negara lainnya, bahwa ditemukan kompensasi berbasis pengetahuan memiliki nilai negatif terhadap inovasi kinerja organisasi pada Pusat Penelitian dan Pelatihan Aparatur Pemerintah di Indonesia. Hal ini dapat disebabkan karena pegawai pemerintah di pada objek tersebut tidak mengharapkan kompensasi finansial terkait inovasi yang dihasilkan. Dengan demikian, kompensasi yang diberikan oleh pusat penelitian dan pelatihan bagi karyawannya adalah non finansial, berupa pemberian kesempatan pengembangan kompetensi melalui kursus, beasiswa pendidikan, pelatihan dan sebagainya. Namun berdasarkan wawancara dengan beberapa karyawan, ditemukan sistem kompensasi non-finansial masih kurang memadai karena pegawai masih menganggapnya sebagai tugas tambahan di luar tugas dasar.

\section{Melakukan Penilaian Dampak Manajemen Pengetahuan}

Penilaian merupakan langkah yang diperhitungkan yang digunakan untuk mengukur dampak manajemen pengetahuan baik dampak finansial maupun nonfinansial. Girard and McIntyre (2010) menjelaskan tentang model Inukshuk yang berisi 5 (lima) faktor pendukung yakni teknologi, kepemimpinan, budaya, proses, 
dan pengukuran. Pengukuran adalah satu-satunya elemen yang memungkinkan pemangku kepentingan untuk menentukan apakah kegiatan manajemen pengetahuan telah berkontribusi pada tujuan strategis organisasi.

Pada pemerintahan Indonesia, karena manajemen pengetahuan masuk dalam program reformasi birokrasi maka monitoring dan evaluasi berada pada Inspektorat Jenderal (Purwasih, 2014). Evaluasi dilakukan bila terdapat pelaksanan yang menyimpang dalam reformasi birokrasi. Namun berdasarkan hasil wawancara penelitian, belum terdapat evaluasi pada Kementerian Perindustrian terhadap sistem aplikasi. Karena tugas evaluasi masuk dalam Inspektorat Jenderal atau Inspektorat Daerah dimana jumlah auditor bersertifikat masih sangat kurang di Indonesia (BPKP, 2014), sehingga evaluasi belum dapat dilaksanakan secara optimal.

\section{KESIMPULAN}

Studi ini melakukan tinjauan literatur secara sistematis untuk memahami manajemen pengetahuan sektor publik dalam teori dan praktik. Pada analisis deskriptif, penulis menemukan berbagai macam proyek penelitian yang mencakup banyak hal pada negara yang berbeda. Penulis menemukan bahwa literatur manajemen pengetahuan didominasi penelitian dari Uni Emirat Arab, India dan Malaysia. Hal ini didukung karena kebijakan pemerintah sehingga mendukung penelitian dalam fokus ini. Selain itu, penulis menemukan bahwa literatur manajemen pengetahuan sektor publik didukung oleh metodologi penelitian yang umumnya dilakukan dengan survei dan hanya sedikit menjelaskan tema penelitian seperti inovasi, sustainability dan lainnya. Hal ini memiliki konsekuensi penting untuk penelitian selanjutnya, karena jika terus menerbitkan tema yang umum, maka hasil penelitian terkait manajemen sektor publik dapat menjadi kurang menarik. Perlu ada eksplorasi tema penelitian lainnya dan menjelajahi batas-batas organisasi sektor publik lainnya serta metodologi yang beragam.

Pada analisis konten, dijelaskan urgensi manajemen pengetahuan diterapkan di Indonesia karena inisiatif manajemen pengetahuan yang berhasil dari negara maju telah berhasil mendapatkan keunggulan kompetitif. Manajemen pengetahuan dapat menjadi salah satu penggerak dalam meningkatkan bidang yang tertinggal 
dan banyak manfaat yang akan dapat dicapai jika menerapkan manajemen pengetahuan sektor publik. Selanjutnya dijelaskan beberapa strategi dalam penerapannya yang diambil dari jurnal terpilih yang dikaitkan dengan kondisi penerapan manajemen pengetahuan pada pemerintah Indonesia.

Studi ini memiliki beberapa keterbatasan. Hanya artikel jurnal di database Scopus yang digunakan pada tinjauan literatur sistematis sehingga berpotensi mengabaikan dengan tanpa sengaja beberapa artikel yang relevan tentang manajemen pengetahuan sektor publik. Namun demikian, seleksi bersifat komprehensif. Selain itu, penelitian ini didasarkan pada analisis dan hasil interpretasi yang terkadang subjektif. Meski dengan keterbatasan, penulis berharap kontribusi ini dapat menjadi rujukan untuk penelitian lebih lanjut. Para peneliti dari Indonesia dapat mengambil kesempatan ini untuk mulai menyelidiki manajemen pengetahuan yang belum tersentuh kedalam isu-isu spesifik seperti sistem manajemen pengetahuan. Selain itu, penelitian selanjutnya dapat melaksanakan penelitian pada organisasi sektor publik lain yang belum diteliti.

\section{DAFTAR PUSTAKA}

Abass, F., Hayat, M., Shahzad, A., \& Riaz, A. J. E. J. o. S. S. (2011). Analysis of knowledge management in the public sector of Pakistan. 19(4), 471-478.

Abdulmuhsin, A. A., Zaker, R. A., \& Asad, M. M. (2021). How exploitative leadership influences on knowledge management processes: the moderating role of organisational citizenship behaviour. International journal of organizational analysis (2005), ahead-of-print(ahead-of-print). doi:10.1108/IJOA-09-2020-2424

Al-Athari, A., \& Zairi, M. (2001). Building benchmarking competence through knowledge management capability - An empirical study of the Kuwaiti context. Benchmarking : an international journal, 8(1), 70-80. doi:10.1108/14635770110383489

Al Ahbabi, S. A., Singh, S. K., Balasubramanian, S., \& Gaur, S. S. (2019). Employee perception of impact of knowledge management processes on public sector performance. Journal of knowledge management, 23(2), 351373. doi:10.1108/JKM-08-2017-0348

Al Yami, M., \& Ajmal, M. M. (2019). Pursuing sustainable development with knowledge management in public sector. VINE journal of information and 
knowledge management systems, 49(4), 568-593. doi:10.1108/VJIKMS-052019-0068

Al Yami, M., Ajmal, M. M., Balasubramanian, S. J. V. J. o. I., \& Systems, K. M. (2021). Does size matter? The effects of public sector organizational size'on knowledge management processes and operational efficiency.

Alatawi, F. M. H., Dwivedi, Y. K., Williams, M. D., \& Rana, N. P. (2012). A review of knowledge management in the public sector across Arab countries: Lessons learnt from developed and developing world. Paper presented at the European, Mediterranean \& Middle Eastern Conference on Information Systems.

Albreiki, S., \& Bhaumik, A. A. A. J. d. (2019). The Influence of Knowledge Management on the Smart Government Effectiveness: An Empirical Study in UAE. 11, 12.

Alvarenga, A., Matos, F., Godina, R., \& C. O. Matias, J. (2020). Digital Transformation and Knowledge Management in the Public Sector. Sustainability (Basel, Switzerland), 12(14), 5824. doi:10.3390/su12145824

Bappenas. (2016). Kajian Internalisasi Manajemen Pengetahuan dalam Penyusunan Kebijakan Bidang Tata Ruang dan Pertanahan. Jakarta

BPKP. (2014). Meningkatan Kompetensi APIP dengan Diklat Auditor Ahli. Retrieved

from http://www.bpkp.go.id/bali/berita/read/11845/0/meningkatan-kompetensiapip-dengan-diklat-auditor-

Cahyaningsih, E., Sensuse, D. I., Wibowo, W. C., Latifah, R., \& Sari, W. P. (2016). NUSANTARA: A new design of knowledge management system in Indonesia. Paper presented at the 2016 International Conference on Information Technology Systems and Innovation (ICITSI).

Chiu, C.-N., \& Chen, H.-H. (2016). The study of knowledge management capability and organizational effectiveness in Taiwanese public utility: the mediator role of organizational commitment. SpringerPlus, 5(1), 1520-1520. doi:10.1186/s40064-016-3173-6

Choy Chong, S., Salleh, K., Noh Syed Ahmad, S., \& Syed Omar Sharifuddin, S.-I. (2011). KM implementation in a public sector accounting organization: an empirical investigation. Journal of knowledge management, 15(3), 497512. doi:10.1108/13673271111137457 
Chu, K.-w. (2016). Leading knowledge management in a secondary school. Journal of knowledge management, 20(5), 1104-1147. doi:10.1108/JKM-10-20150390

Colnar, S., \& Dimovski, V. J. M. J. o. C. M. I. (2017). Knowledge management initiatives benefits for the Slovenian public sector. 22(Special Issue), 145161.

Cong, X., Li-Hua, R., \& Stonehouse, G. (2007). Knowledge management in the Chinese public sector: empirical investigation. Journal of technology management in China, 2(3), 250-263. doi:10.1108/17468770710825188

De Angelis, C. T. (2013). A knowledge management and organizational intelligence model for public administration. International Journal of Public Administration: Knowledge Management and Public Administration: Good Bedfellows or Potential Sparring Partners, 36(11), 807-819.

Edge, K. (2005). Powerful public sector knowledge management: a school district example. Journal of knowledge management.

Farazmand, A. (2017). Governance reforms: The good, the bad, and the ugly; and the sound: Examining the past and exploring the future of public organizations. Public Organization Review, 17(4), 595-617.

Girard, J. P., \& McIntyre, S. (2010). Knowledge management modeling in public sector organizations: a case study. International Journal of Public Sector Management, 23(1), 71-77. doi:10.1108/09513551011012330

Irawanto, D. W. J. J. o. D. M. (2009). An analysis of national culture and leadership practices in Indonesia. 4(2), 41-48.

Jesson, J., Matheson, L., \& Lacey, F. M. (2011). Doing your literature review: Traditional and systematic techniques.

Joshi, H., Farooquie, J. A., \& Chawla, D. (2016). Knowledge Management Practices in Indian Organizations-A Sectoral Comparison. Vision (New Delhi, India), 20(3), 211-223. doi:10.1177/0972262916651534

Karim, N. S. A., \& Valaei, N. J. I. J. o. K. M. S. (2020). Does ambidexterity in leadership strategies influence public sectors' KM readiness in terms of SECI processes? , 11(1), 20-40.

Kemenkeu. (2019). Ini Sederet Tantangan Dana Riset. Retrieved from https://www.kemenkeu.go.id/publikasi/berita/ini-sederet-tantangan-danariset/ 
KemenpanRB. (2011). Permenpan RB Nomor 14 Tahun 2011 tentang Pedoman Pelaksanaan Program Manajemen Pengetahuan (Knowledge Management).

Krippendorff, K. (2013). Content analysis: An introduction to its methodology: Sage publications.

Laihonen, H., \& Kokko, P. (2020). Knowledge management and hybridity of institutional logics in public sector. Knowledge management research practice, $1-15$.

Liebowitz, J. (2003). Addressing the Human Capital Crisis in the Federal Government: A Knowledge Management Perspective. Burlington: Taylor \& Francis Group.

Mafabi, S., Munene, J., \& Ntayi, J. (2012). Knowledge management and organisational resilience: Organisational innovation as a mediator in Uganda parastatals. Journal of Strategy Management Accounting Research.

Magnier-Watanabe, R., Benton, C., Senoo, D. J. K. m. r., \& practice. (2011). A study of knowledge management enablers across countries. 9(1), 17-28.

McAdam, R., Hazlett, S. A., \& Casey, C. (2005). Performance management in the UK public sector: Addressing multiple stakeholder complexity. The International journal of public sector management, 18(3), 256-273. doi:10.1108/09513550510591542

Mitrović, Z., Obradović, V., \& Suknović, M. J. S. J. o. M. (2018). Knowledge management in the public sector: The case of Serbian local government. 13(2), 293-309.

Pandey, S. C., \& Dutta, A. J. I. J. o. K.-B. D. (2015). Knowledge infrastructure capabilities and knowledge management: case of an Indian public sector undertaking. 6(1), 50-64.

Praditya, D. (2012). Knowledge Management dalam Pemerintahan Daerah. Jurnal Penelitian Komunikasi, 15(2).

Prasojo, E. (2020). Memimpin Reformasi Birokrasi: Kompleksitas dan Dinamika Perubahan Birokrasi Indonesia: Prenada Media.

Purwasih, N. (2014). Strategi Manajemen Pengetahuan dala Mendukung Program Reformasi Birokrasi: Studi Kasus Kementerian Perindustrian. Universitas Indonesia. 
Rachmawati, U. A., \& Sensuse, D. I. (2010). Perspektif Knowledge Management pada E-Government di Indonesia. Paper presented at the Seminar Nasional Aplikasi Teknologi Informasi (SNATI).

Rakhmani, I., Sakhiyya, Z., Ramadhan, A., \& Agahari, W. (2020). Melakukan Riset di Indonesia.

Rowley, J., \& Seba, I. (2010). Knowledge management in UK police forces. Journal of knowledge management, 14(4), 611-626. doi:10.1108/13673271011059554

Salleh, K. (2013). Knowledge sharing and knowledge management modelling in public sector accounting organisation: case evidence from Malaysia. International Journal of Knowledge-Based Development, 4(4), 363-381.

Salleh, K., Ahmad, S. N. S., Ikhsan, S. O. S. S., \& Chong, S. C. J. E. G., An International Journal. (2011). Perceived KM benefits and obstacles: a survey on government institutions. 8(4), 327-342.

Sensuse, D. I., Cahyaningsih, E., \& Wibowo, W. C. J. P. C. S. (2015). Knowledge management: organizational culture in Indonesian government human capital management. 72, 485-494.

Siddiqui, S. H., Rasheed, R., Nawaz, M. S., \& Abbas, M. (2019). Knowledge Sharing and Innovation Capabilities: The Moderating Role of Organizational Learning. Pakistan Journal of Commerce and Social Sciences, 13(2), 455486.

Susanty, A. I., Yuningsih, Y., \& Anggadwita, G. (2019). Knowledge management practices and innovation performance. Journal of Science and Technology Policy Management, 10(2), 301-318. doi:10.1108/JSTPM-03-2018-0030

Titi Amayah, A. (2013). Determinants of knowledge sharing in a public sector organization. Journal of knowledge management, 17(3), 454-471. doi:10.1108/JKM-11-2012-0369

Tranfield, D., Denyer, D., \& Smart, P. (2003). Towards a Methodology for Developing Evidence-Informed Management Knowledge by Means of Systematic Review. British journal of management, 14(3), 207-222. doi:10.1111/1467-8551.00375

UNDP. (2020). Global Knowledge Index. Retrieved from Dubai:

Ward, V., House, A., \& Hamer, S. (2009). Developing a Framework for Transferring Knowledge Into Action: A Thematic Analysis of the Literature. 
Journal of health services research \& policy, 14, 156-164. doi:10.1258/jhsrp.2009.008120

Wiig, K. M. (2002). Knowledge management in public administration. Journal of knowledge management, 6(3), 224-239. doi:10.1108/13673270210434331

Zhou, Z., Gao, F. J. I. J. o. C. S., \& Security, N. (2007). E-government and Knowledge Management. 7(6), 285-289. 